【論 文】

UDC : 69.022. $1: 66.078 .2: 539.213$

\title{
ひびわれの生じたコンクリート壁からの 気体漏洩に関する実験研究
}

一気体の圧縮性を考慮した実験式の検討一

$\begin{array}{lllll}\text { 正会員 } & \text { 鈴 } & \text { 木 } & \text { 敏 } & \text { 郎* } \\ \text { 正会員 } & \text { 滝 } & \text { 口 } & \text { 克 } & \text { 己** } \\ \text { 正会員 } & \text { 堀 } & \text { 田 } & \text { 久 } & \text { 人*** } \\ \text { 正会員 } & \text { 井 } & \text { 出 } & & \text { 豊**** }\end{array}$

\section{$\S 1$. 序}

本論文は, 原子力関連施設の設計において重要性を増 してきているひびわれの生じた鉄筋コンクリート壁を通 しての気体漏洩問題に関する第 2 報である。

前報1において，筆者らは鉄筋コンクリート壁の気体 漏洩問題の中で最も基本的なコンクリート自体について 単一ひびわれを通しての気体漏洩実験方法を提示し, 実 験結果をもとに次のように結論した。

（1）ひびわれを通しての気体漏洩量は壁両端の圧力 差に比例する範囲が存在する。

（2）（1）で述べた範囲内であれば，単位ひびわれ 長さ, 単位時間当たりの漏洩量 $Q$ は, 壁厚 $T$, ひびわ 机幅 $W$, 壁両端の圧力差 $\Delta p$, 気体の粘性係数 $\mu$ により，

$$
Q=\bar{\alpha} \cdot \Delta p \cdot W^{3} /(\mu \cdot T)
$$

で表される。

（3）（1）式の係数 $\bar{\alpha}$ はひびわれ幅 $W$ の関数となっ ており，ひびわれ幅の増加とともに増大する。 $\bar{\alpha} の$ 值は, 二次元ポアズイ工流を仮定したときの係数 $1 / 12$ よりは るかに小さい。

本論文は,コンクリート壁の気体漏洩量に関して新た に気体の圧縮性を考虑した実験式を提案し，この実験式 と新たな漏洩実験結果により前報で得た結論について検 討を行ったものである。

まず，前報で提示した実験結果について気体の圧縮性 を考慮して再整理を行い，流れを等温圧縮性流れ之仮定 した実験式の提案を行う。

続いて, 粗骨材の最大粒径を変化させた試験体; アル ミニウムのモデル骨材を用いて骨材形状を変化させた試 験体，およびガラス板を用いた理想ひびわれモデルの試 験体について前報と同様の気体漏洩実験による実験結果 を示し，前報において（1）式の比例係数 $\bar{\alpha}$ を最大骨

\footnotetext{
* 東京工業大学 教授.工博

** 東京工業大学 助教授. 工博

**** 東京工業大学 助手

**** 東京工業大学 大学院生 (昭和 62 年 6 月 10 日原稿受理)
}

材粒径の関数と仮定したこと，理想化したひびわれ内の 気体の流れを二次元ポアズイユ流と仮定したことについ て,その妥当性を検討した。

さらに，新たに提示した実駼結果の評価式を用いて前 報の実験式（(1) 式）の意味について再考し，適切な 付帯条件が設定された場合は，（1）式の形がコンクリー 卜壁のひびわれを通した気体漏洩に関する実用式となり 得ることを示す。

\section{§2. 試験体および実験方法}

試験体リストをTable 1 に示す。試験体名は［壁厚の $\mathrm{cm}$ 表示 $]$ 一[骨材の種類, A, B, C, D , E，ガラス板の試 験体 $\mathrm{G}$ ]一[同一試験体を区別する記号 1，2］とした。な お $\mathrm{A}$ シリーズの 6 体の試験体は前報で提示した式験体で ある。B，Cシリーズの試験体は骨材粒径の影響を調へ る目的で作製されたもので，粗骨材の最大粒径を 25 mm, $15 \mathrm{~mm}$ としている。Fig.1(a) にA シリーズのコ ンクリートの骨材の粒度分布を, Fig. 1(b) にB, C シ リーズのコンクリートの骨材の粒度分布を示す。 D, E シリーズの試験体は骨材形状の影響を調べるためのもの で，粗骨材としてそれぞれ直径 $24.8 \mathrm{~mm}$ の球亡一辺 20 $\mathrm{mm}$ の立方体のアルミニウムを用いている。骨材にアル ミニウムを用いたのは，比重が通常の粗骨材とほぼ同じ であり，コンクリート打設時に骨材分離を起こしにくい と判断したためである。アルミニウムの表面は耐アリカ リ処理を施している。A〜E シリーズの試験体の形状は, 前報で提示したものと同一である。Fig. 2に，その一例 として壁厚 $30 \mathrm{~cm}$ の試験体の試験体図を示す。

Gシリーズの試験体は，ひびわれ面を理想化して滑ら かな平面とした場合に流れがどのようになっているかを 調べる目的で作製したものである。Fig. 3 に示すように 2 枚のガラス板の間に厚さ $0.3 \mathrm{~mm}$ のスペーサーをはさ み，ほかの試験体之同一の圧力箱（ゴムと鋼板）が付く ように上下にブロック状の木材を取り付け，4 隅の鋼棒 で締め付けた。壁厚は $15 \mathrm{~cm}$ ，すき間長さは $10 \mathrm{~cm}$ ，ひ びわれ幅に相当するガラス板のすき間幅は $0.3 \mathrm{~mm}$ であ 
Table 1 List of specimens

\begin{tabular}{|c|c|c|c|c|}
\hline Name & Wall Thickness & Concrete & Fine Aggregate & Coarse Aggregate \\
\hline $60-A-1$ & $60(\mathrm{~cm})$ & \multirow{6}{*}{ A } & \multirow{6}{*}{$\begin{array}{l}\text { Sand } \\
\qquad 5 \quad(\mathrm{~mm})\end{array}$} & \multirow{6}{*}{$\begin{array}{r}\text { Crushed Gravel } \\
10 \sim 20(\mathrm{~mm})\end{array}$} \\
\hline $60-A-2$ & $60(\mathrm{~cm})$ & & & \\
\hline $30-A-1$ & $30(\mathrm{~cm})$ & & & \\
\hline $30-A-2$ & $30(\mathrm{~cm})$ & & & \\
\hline $15-\mathrm{A}-1$ & $15(\mathrm{~cm})$ & & & \\
\hline $15-A-2$ & $15(\mathrm{~cm})$ & & & \\
\hline $30-B$ & $30(\mathrm{~cm})$ & B & \multirow{4}{*}{$\begin{array}{l}\text { Sand } \\
\qquad 2.5(\mathrm{~mm})\end{array}$} & Crushed Gravel: $10 \frown 25(\mathrm{~mm})$ \\
\hline $30-\mathrm{C}$ & $30(\mathrm{~cm})$ & C & & Crushed Gravel: $2.5 \sim 15(\mathrm{~mm})$ \\
\hline $15-D$ & $15(\mathrm{~cm})$ & D & & Spherical Aluminum: $D=24.8$ (mm) \\
\hline $15-\mathrm{E}$ & $15(\mathrm{~cm})$ & $E$ & & Cubical Aluminum: $20 \times 20 \times 20(\mathrm{~mm})$ \\
\hline $15-6$ & $15(\mathrm{~cm})$ & \multicolumn{3}{|c|}{$\begin{array}{l}\text { Specimen for leakage test of Idealized crack. } \\
\text { Idealized crack was made of two parallel glass plates. }\end{array}$} \\
\hline
\end{tabular}

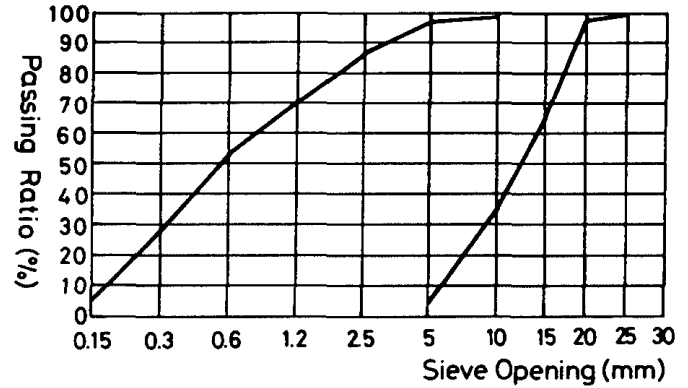

(a) Concrete $\mathrm{A}$

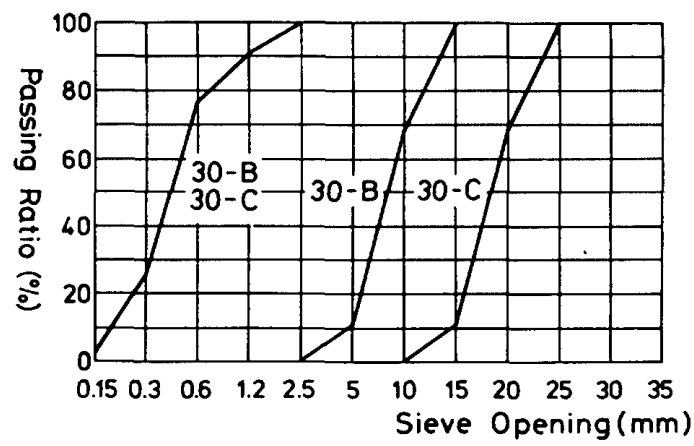

(b) Concrete $\mathrm{B}$ and $\mathrm{C}$

Fig. 1 Sieve analysis curves

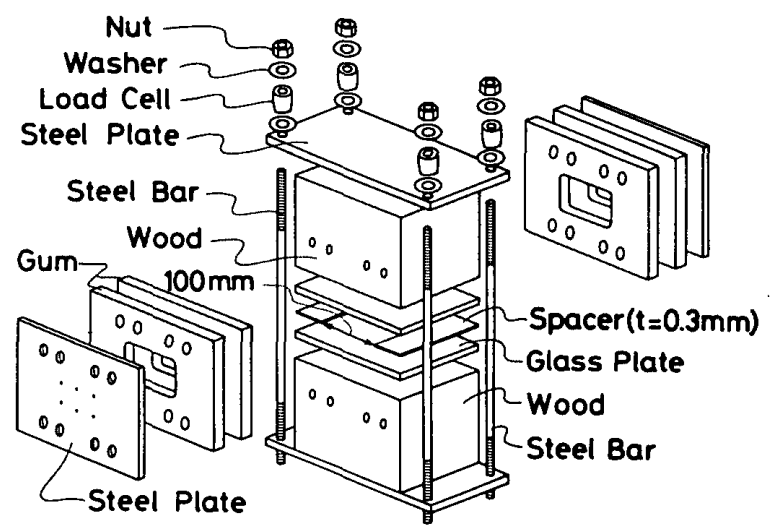

Fig. 3 Construction of $15-\mathrm{G}$
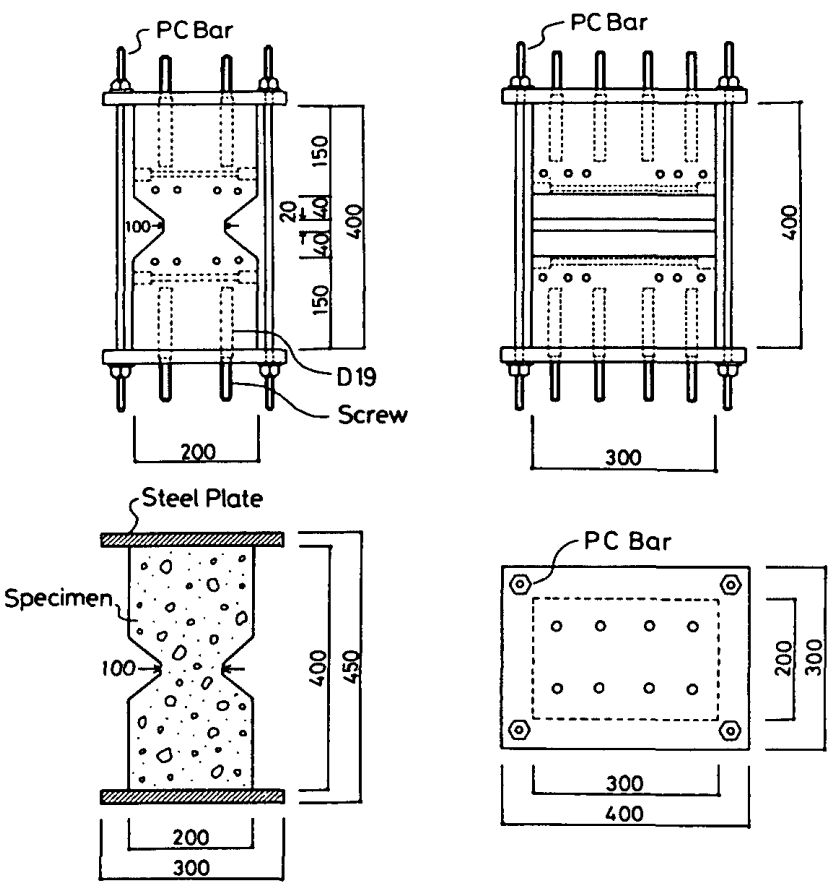

Fig. 2 Specimen $(T=30 \mathrm{~cm})$

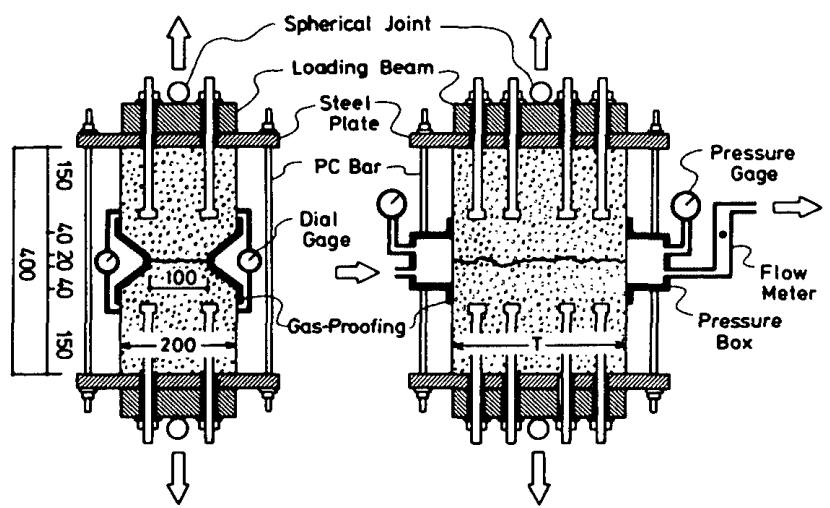

Fig. 4 Concrete specimen and test set up 
る。

A E シリーズの試験体の実験方法の概略を Fig. 4 に 示す。試験体を球座を介してアムスラー $100 \mathrm{t}$ 万能試験 機で引張り, くさび状の部分に引張りひびわれを発生さ せる。荷重の制御と，PC 鋼棒の締め付けによりひびわ れ幅を制御し，ダイヤルゲージでひびわれ幅を測定する。 壁両端には，圧力計を取り付けた圧力箱をセットし，一 方の圧力箱に酸素ボンベより酸素ガスを送る。もう一方 の圧力箱には，流量の測定範囲の異なる面積式流量計を 5 器継ぎ, 適当な流量計 1 つを選び, 漏洩量の測定を行 う。各流量計の流出端は大気に開放されている。ひびわ れ幅は $0.05 \mathrm{~mm}$ 間隔で変化させ, 同じひびわれ幅で压 力を変えて漏洩量を数点測定した。

一方，Gシリーズの試験体では，ひびわれ幅に相当す る 2 枚のガラス板のすき間幅の制御は試験体の 4 隅に配 した鋼棒の締如付けにより行い，すき間幅の測定には， ひびわれ観察用のスケール (最小目盛 $1 / 100 \mathrm{~mm})$ 付ルー ペ $(\times 100)$ を用いた。漏洩量の測定方法は, A E E シリー ズと同様である。

試験体養生およびゴムシーリング方法は前報と同様で あるので，その詳細については前報を参照されたい。

\section{§3. 実験結果および考察}

3.1. 圧縮性流体の一次元流れの基礎式

はじめに，実験結果を整理する上で基礎となる圧縮性 流体の一次元流れ゙にてつて述べる。

Fig. 5 に示すように，幅 $B$, すき間 $W$ の長方形断面 を有する管内の一次元定常流れを考える。壁面には単位 面積当たり $\tau_{w}$ のせん断力が作用し，管軸方向に $d x$ 隔 てた所で断面内の平均流速 $\bar{u}$, 平均圧力 $\bar{P}$, 平均温度 $\bar{T}_{e m}$ がそれぞれ $d \bar{u}, d \bar{P}, d \bar{T}_{e m}$ 変化したものとする。

運動量保存の法則, 連続条件, 気体の状態方程式より 次式が成り立つ ${ }^{3)}$ 。

$$
\begin{aligned}
& \bar{\rho} \cdot \bar{u} \cdot A \cdot[(\bar{u}+d \bar{u})-\bar{u}]=\bar{P} \cdot A-(\bar{P}+d \bar{P}) \cdot A \\
& -\tau_{w} \cdot A_{s} \\
& G=\bar{\rho} \cdot \bar{u} \cdot A=\text { const. } \\
& \bar{P}=\bar{\rho} \cdot R \cdot \bar{T}_{e m}
\end{aligned}
$$

ここに, $\boldsymbol{\rho}$ は断面内の気体の平均密度, $A$ は管の断面積 $(=B \cdot W), A_{s}$ は壁面の表面積 $(=2 \cdot B \cdot d x), G$ は単 位時間に断面を通過する気体の質量 (マス流量)， $R$ は 気体定数である。

ここで壁面せん断応力 $\tau_{w}$ を単位体積当たりの気体の 運動エネルギーで除した值

$$
f \equiv \tau_{w} /\left(\frac{1}{2} \cdot \bar{\rho} \cdot \bar{u}^{2}\right) \cdots
$$

を摩擦係数と定義する。摩擦係数 $f$ はレイノルズ数お よび壁面粗さの関数になることが一般に知られている。 この場合，レイノルズ数はマス流量が一定であることか ら管内で一定，壁面粘さも管内で一定であることから摩
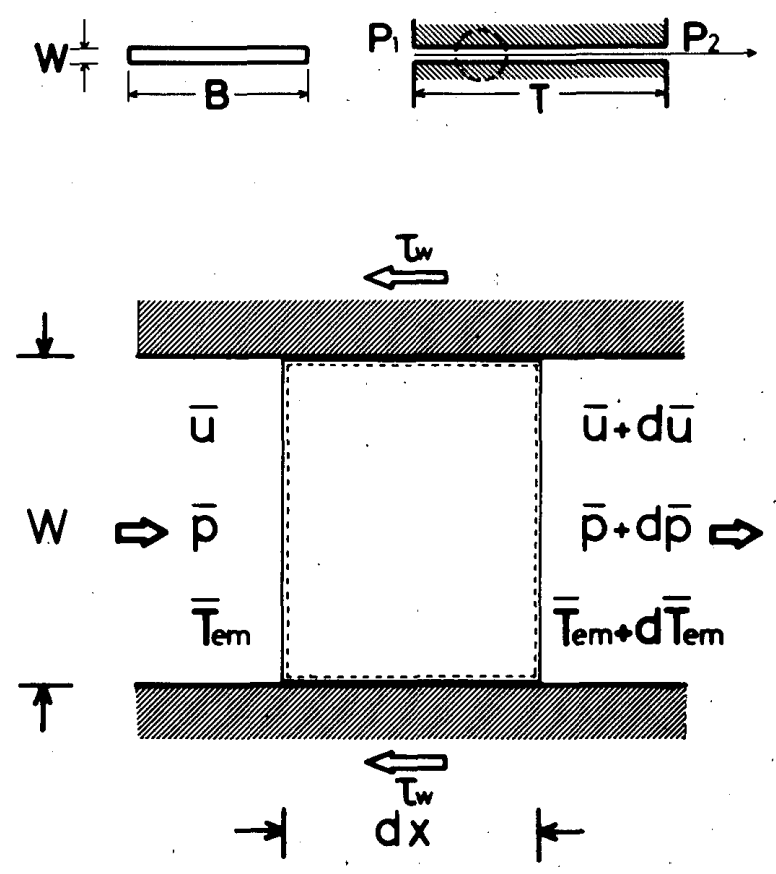

Fig. 5 One dimensional compressive flow

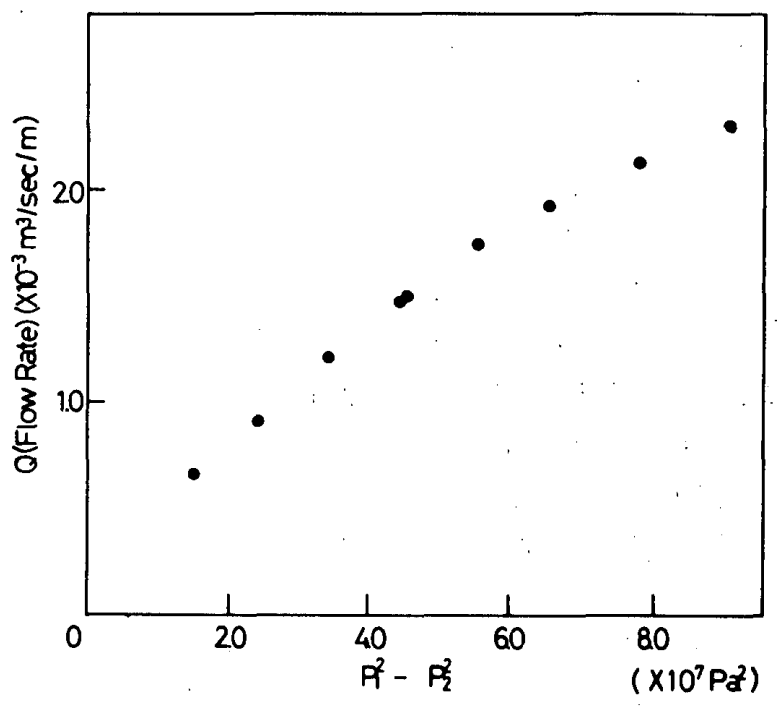

Fig. $6 \quad Q-\left(P_{1}^{2}-P_{2}^{2}\right)$ relationship

擦係数も管内で一定とみなすことができる。

(3)，（4)，（5）式を用いて（2）式を変形すれば,

$$
\frac{d \bar{u}}{\bar{u}}=-\frac{d \bar{P}}{\bar{\rho} \cdot \bar{u}^{2}}-\frac{f}{W} d x
$$

を得る。さらに, 此較的流速が遅く, 管路が偏平で壁面 の表面積が大きい場合, 外部之の熱の授受により流れは 等温とみなせる。

$$
\bar{T}_{e m}=T_{0}=\text { const. }
$$

（6）式を（7）式の条件下で，管路の長さを $T$; 上流 端の圧力を $P_{1}$, 下流端の圧力を $P_{2}$ として解くと, 次式 を得る。

$$
f \cdot \frac{T}{W}=\frac{B^{2} \cdot W^{2} \cdot\left(P_{1}^{2}-P_{2}^{2}\right)}{2 \cdot G^{2} \cdot R \cdot T_{0}}+\ln \frac{P_{2}}{P_{1}}
$$

（8）式を温度 $T_{0}$, 圧力 $P_{0}$ における単位ひびわれ長さ, 
単位時間当たりの体積流量 $Q$ で表せば，

$$
f \cdot \frac{T}{W}=\frac{W^{2} \cdot\left(P_{1}^{2}-P_{2}^{2}\right)}{2 \cdot \rho_{0} \cdot P_{0} \cdot Q^{2}}+\ln \frac{P_{2}}{P_{1}}
$$

となる。ここに $\rho_{0}$ は温度 $T_{0}$, 圧力 $P_{0}$ における気体の 密度である。

\section{2 気体の圧縮性を考慮した実験式}

本報で提示する気体の圧縮性を考慮した実験式は（9） 式をもとに，摩擦係数 $f$ を実験定数として求めんとす るものである。ひびわれ面の凹凸による影響を摩擦係数 として把えることでひびわれによるすき間形状は，単純 に上記のような長方形断面の管路に置き換え得るものと 考えている。また実験における気体の流速はマッ八数で 概算 $10^{-2}$ のオーダーであり，ひびわれによるすき間形 状が非常に偏平であることから，流れを等温とみなして も差しつかえないものと思われる。

マッ八数で $10^{-2}$ 程度のオーダーの流速の遅い流れで はさらに（9）式の右辺第 2 項は第 1 項に比べ微小とな り，(第 2 項は第 1 項に比べ $10^{-3} \sim 10^{-4}$ のオーダーとな る）無視し得る。そこで，（9）式で右辺第 2 項を無視 した。

$$
f \cdot \frac{T}{W}=\frac{W^{2} \cdot\left(P_{1}^{2}-P_{2}^{2}\right)}{2 \cdot \rho_{0} \cdot P_{0} \cdot Q^{2}}
$$

により，摩擦係数 $f$ を求める形で実験結果を整理した。 実験結果は, 気体漏洩量をすべて $20^{\circ} \mathrm{C}, 1.013 \times 10^{5} \mathrm{~Pa}$ ( 1 気圧)換算の体積流量で表している。したがって(10) 式中, $P_{0}$ は $1.013 \times 10^{5} \mathrm{~Pa}, \rho_{0}$ は $20^{\circ} \mathrm{C}, 1.013 \times 10^{5} \mathrm{~Pa}$ における酸素ガスの密度 $\left(1.33 \mathrm{~kg} / \mathrm{m}^{3}\right)$ である。

Fig. 6 K, 実験結果の流量 $Q$ と壁両端の圧力 $P_{1}^{2}-P_{2}^{2}$ の関係の一例を示す。は実駼結果をプロットしたもの である。Q-( $\left.P_{1}^{2}-P_{2}^{2}\right)$ 関係は比例関係ではないがなめら かな曲線で表される。また，Fig.7(a)，(b)にAシリー ズのコンクリートのひびわれ幅が $0.15 \mathrm{~mm}, 0.20 \mathrm{~mm}$ における流量 $Q$ と（10）式より求めた摩擦係数 $f$ の関 係を示す。壁厚 $15 \mathrm{~cm}, 30 \mathrm{~cm}, 60 \mathrm{~cm}$ の試験体の実験デー 夕をそれぞれ $\Delta, \square ，$ ○で表している。壁厚によって同 じ流量での摩擦係数の值に多少のばらつきがあるが，こ れは，壁厚が厚くなるほどひびわれ幅の制御が困難にな ることや，試験体により厳密には同じひびわれ幅になっ ていないこと等, 実験誤差によるものがあり， $f-Q$ 関 係は壁厚によらず一定であるといえる。以上より、ひび われの生じたコンクリート壁からの気体漏洩量は（10) 式により評価できることがわかる。

Fig. 8(a) ( f) は, 摩擦係数と流量の積 $f \cdot Q$ と流量 $Q$ の関係を示したものである。実験データはFig.8と 同様, $\mathrm{A}$ シリーズのコンクリートのデータである。 $f \cdot Q$ はひびわれ幅によって傾き, 切片が異なるものの いずれも流量 $Q$ の 1 次関数で表される。図中の実線は 回帰計算により求めた直線を示している。回帰計算より

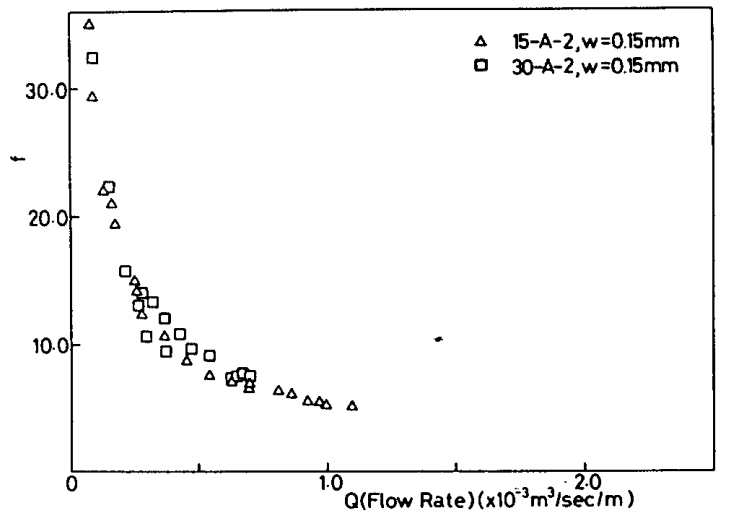

(a) $W=0.15 \mathrm{~mm}$

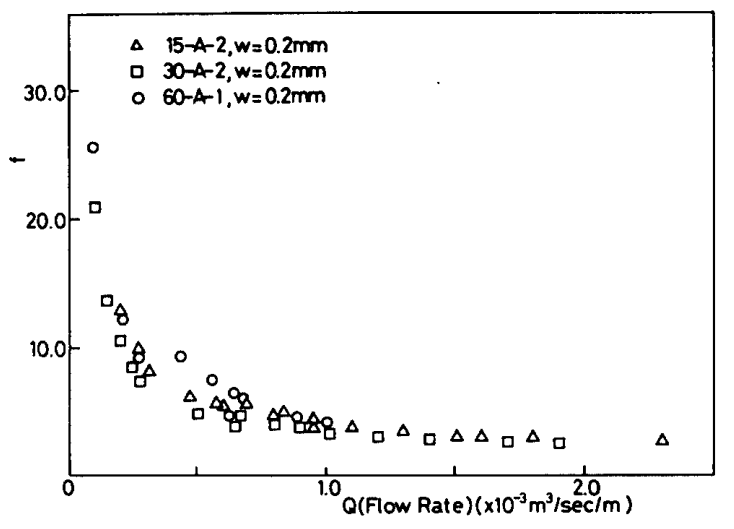

(b) $W=0.20 \mathrm{~mm}$

Fig.7 $f-Q$ relationship of $15-\mathrm{A}-2,30-\mathrm{A}-2$ and $60-\mathrm{A}-1$

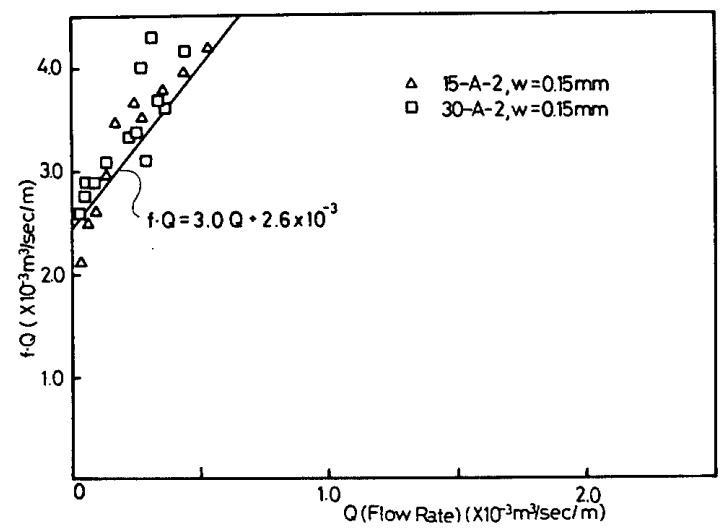

(a) $W=0.15 \mathrm{~mm}$

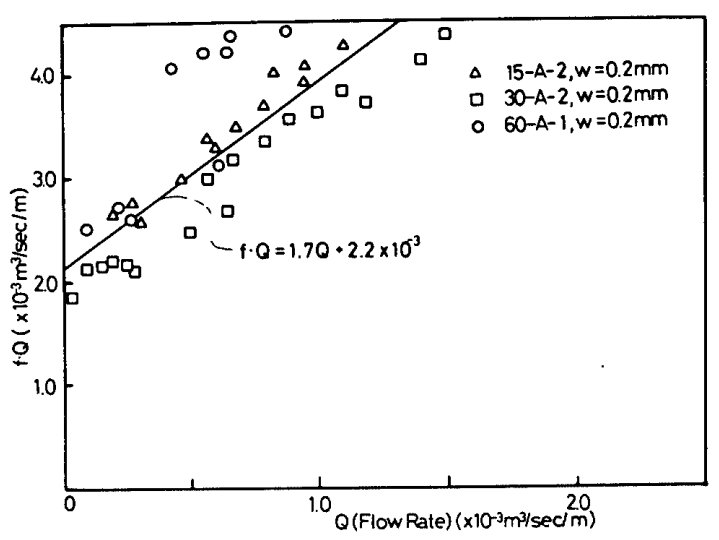

(b) $W=0.20 \mathrm{~mm}$ 


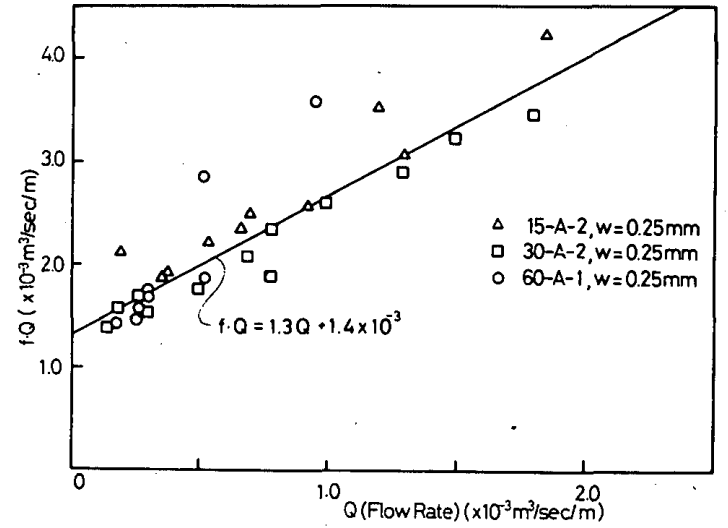

(c) $W=0.25 \mathrm{~mm}$

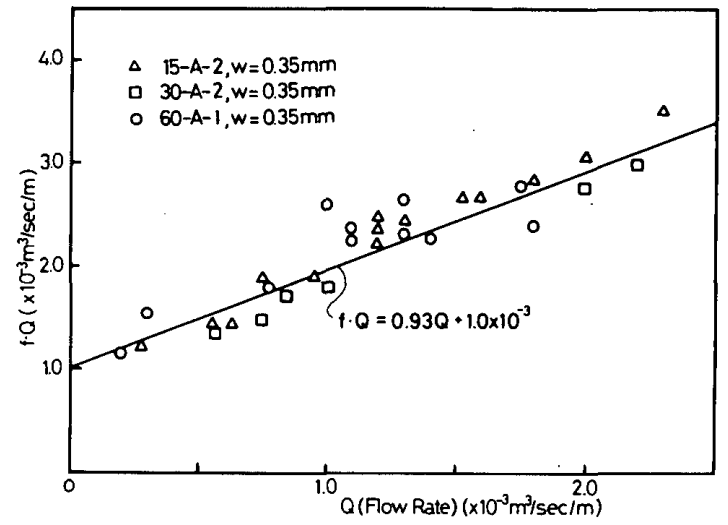

(e ) $W=0.35 \mathrm{~mm}$

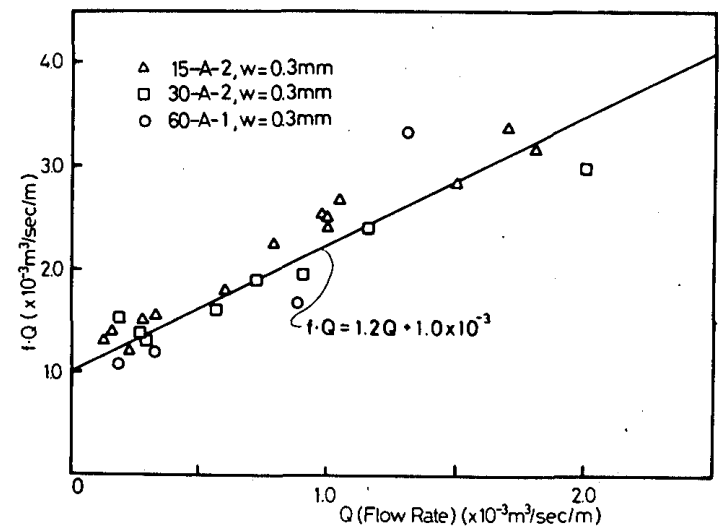

(d) $W=0.30 \mathrm{~mm}$

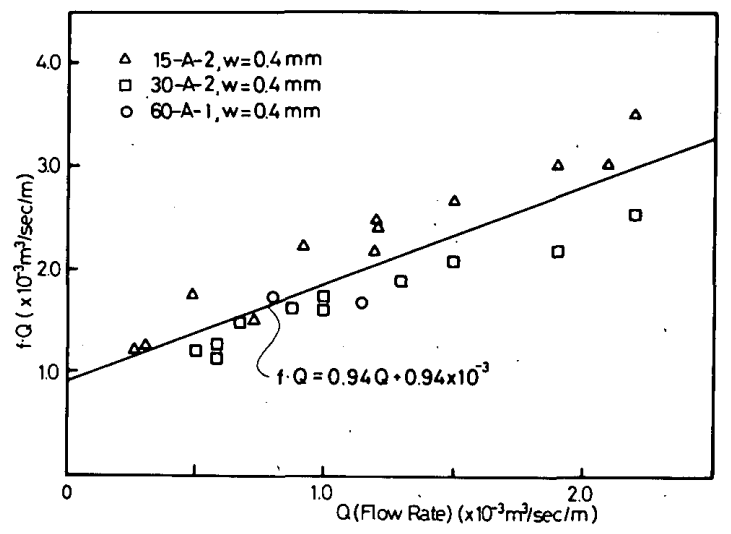

(f) $W=0.40 \mathrm{~mm}$

Fig:8 $f \cdot Q-Q$ relationship of $15-\mathrm{A}-2,30-\mathrm{A}-2$ and $60-\mathrm{A}-1$

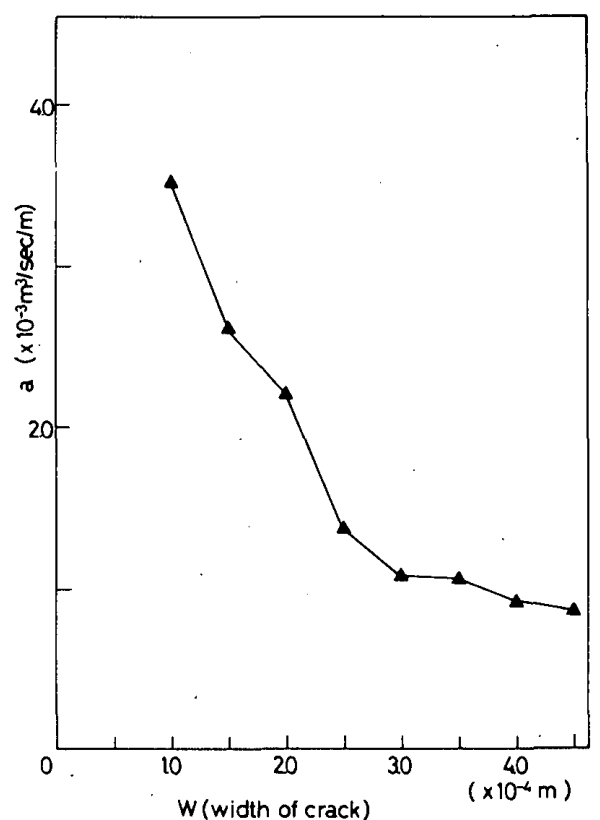

Fig. $9 a-W$ relationship of $15-\mathrm{A}-1,15-\mathrm{A}-2,30-\mathrm{A}-1,30-\mathrm{A}-2$, $60-\mathrm{A}-1$ and $60-\mathrm{A}-2$

求めた切片 $a$ ，傾き $b$ とひびわれ幅 $W$ の関係を示した のが Fig. 9，Fig.10である。切片，傾きともひびわれ 幅が増加すると減少する。摩擦係数 $f$ は, ひびわれ幅 $W$ ，流量 $Q$ の関数になっており，次式で表せる。

$$
f=a(W) / Q+b(W)
$$

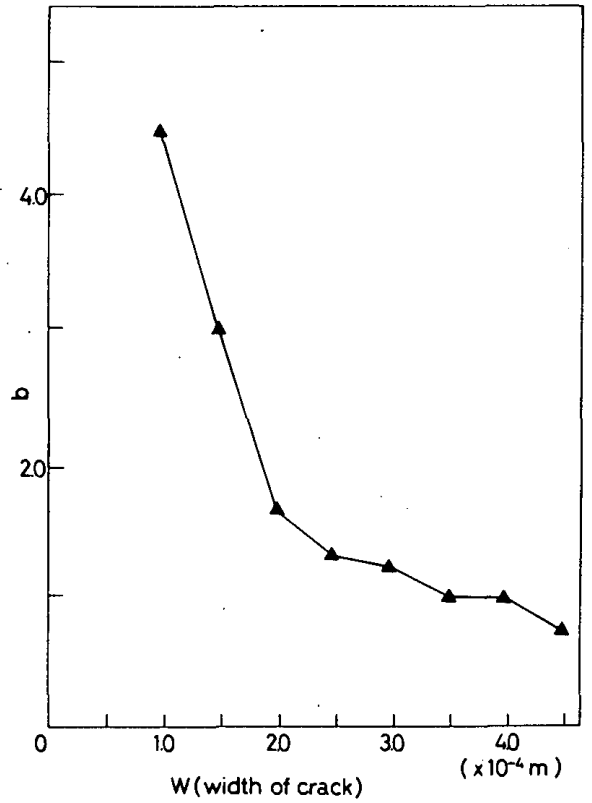

Fig. $10 b-W$ relationship of $15-A-1, \quad 15-A-2, \quad 30-A-1$, $30-A-2,60-A-1$ and $60-A-2$

（10）式，(11）式により，コンクリート壁のひびわれか らの気体漏洩量は, ひびわれ幅, 壁厚, 壁両端の圧力と 関係づけられる。

3.3 ひびわれを理想化した場合の気体の流れ,

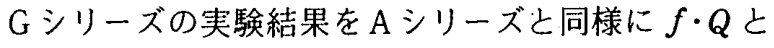


$Q$ の関係でFig.11 に示す。の゙実験結果である。 $f \cdot Q$

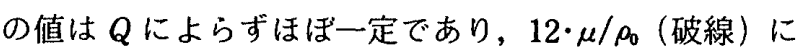
近い值をとっている。 $\mu$ は気体の粘性係数である。この $f \cdot Q$ の一定值 $\left(12 \cdot \mu / \rho_{0}\right)$ はすき間内の流速分布が気体の 分子粘性により, 放物線状になるときの理論值である。 (10) 式に $f \cdot Q=12 \cdot \mu / \rho_{0}$ を代入すれば次式を得る。

$$
Q=\frac{1}{12} \cdot \frac{W^{3}}{\mu \cdot T} \cdot \frac{\left(P_{1}^{2}-P_{2}^{2}\right)}{2 \cdot P_{0}}
$$

$P_{1}, P_{2}$ が極めて $P_{0}$ に近ければ (12) 式は二次元ポアズ イユ流 ${ }^{2)}$ 表す式に一致する。ひびわれを理想化した場 合, 気体の流れは二次元ポアズイユ流に極めて近いもの

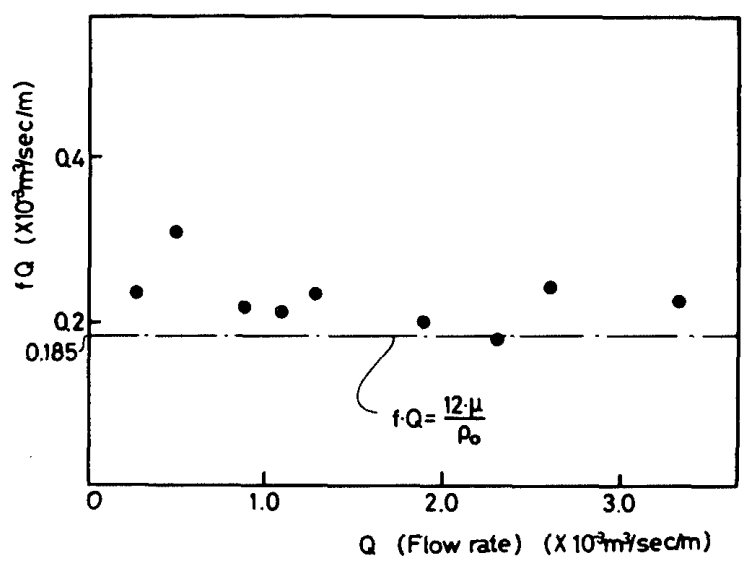

Fig. $11 f \cdot Q-Q$ relationship of $15-G$

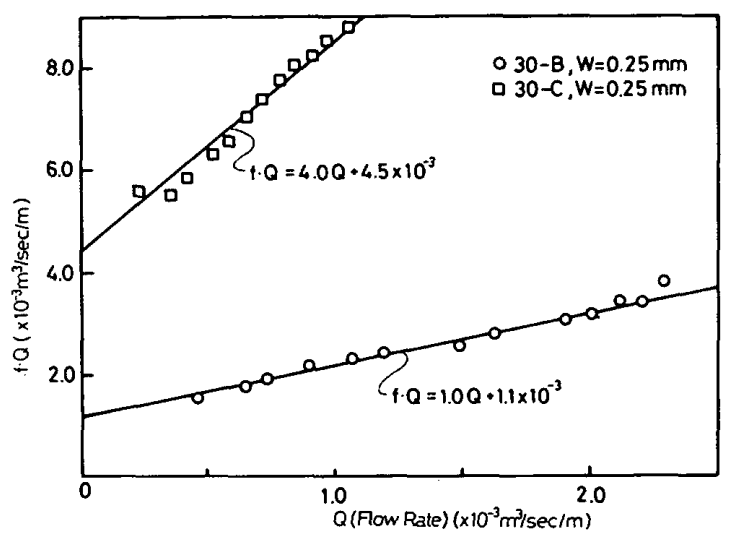

(a) $W=0.25 \mathrm{~mm}$

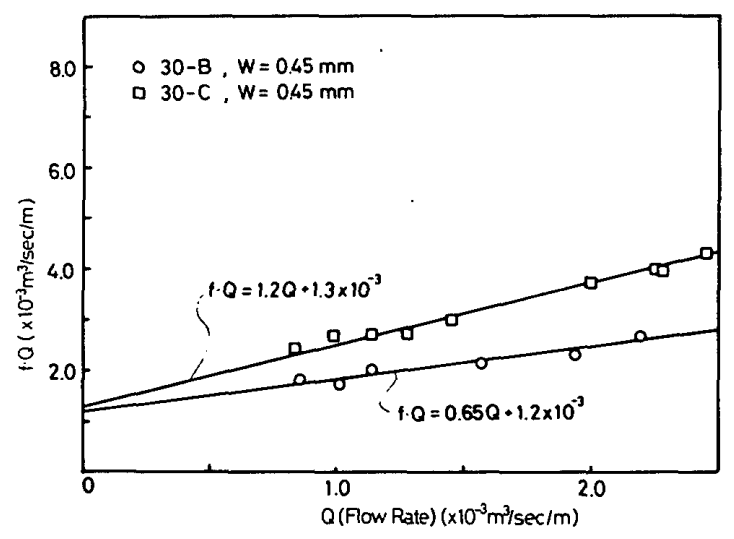

(b) $W=0.45 \mathrm{~mm}$

Fig.12 $f \cdot Q-Q$ relationship of $30-\mathrm{B}$ and $30-\mathrm{C}$
となっていることが実際に確かめられた。

\section{4 骨材粒径，骨材形状の影響}

Fig. 12 に骨材粒径の異なる B，C シリーズのコンク リートに関して，Fig. 13 に骨材形状の異なる D, E シ リーズについて, $f \cdot Q-Q$ 関係図を示す。いずれの試験 体においても $f \cdot Q$ と $Q$ は值線関係で表され, およそ通

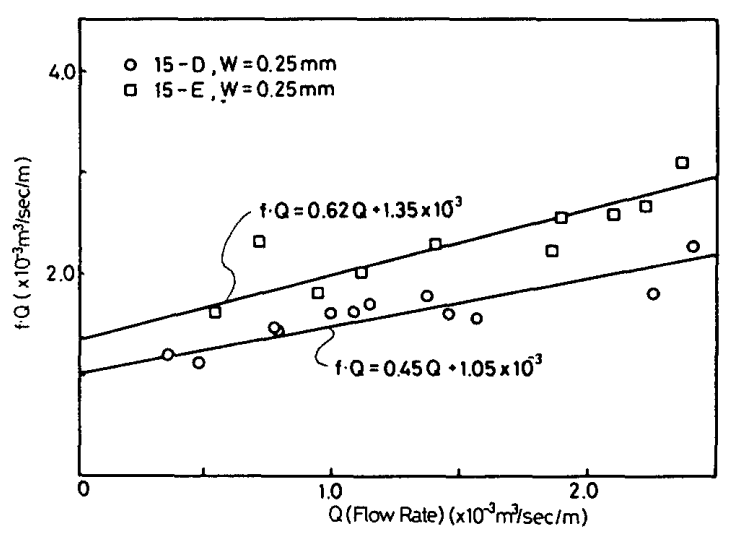

(a) $W=0.25 \mathrm{~mm}$

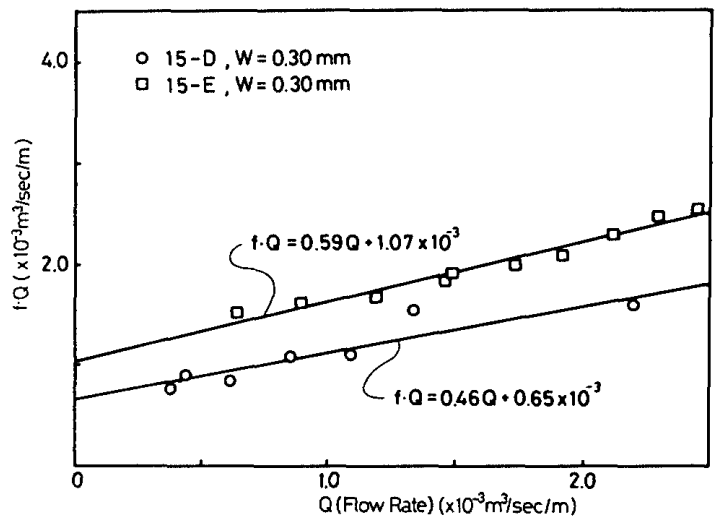

(b) $W=0.30 \mathrm{~mm}$

Fig. $13 f \cdot Q-Q$ relationship of $15-\mathrm{D}$ and $15-\mathrm{E}$

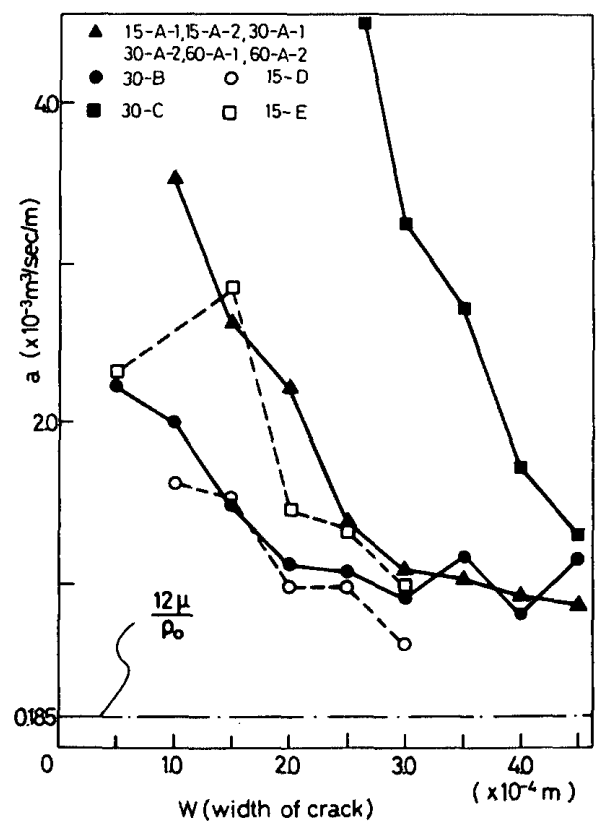

Fig. $14 a-W$ relationship of all the specimens 


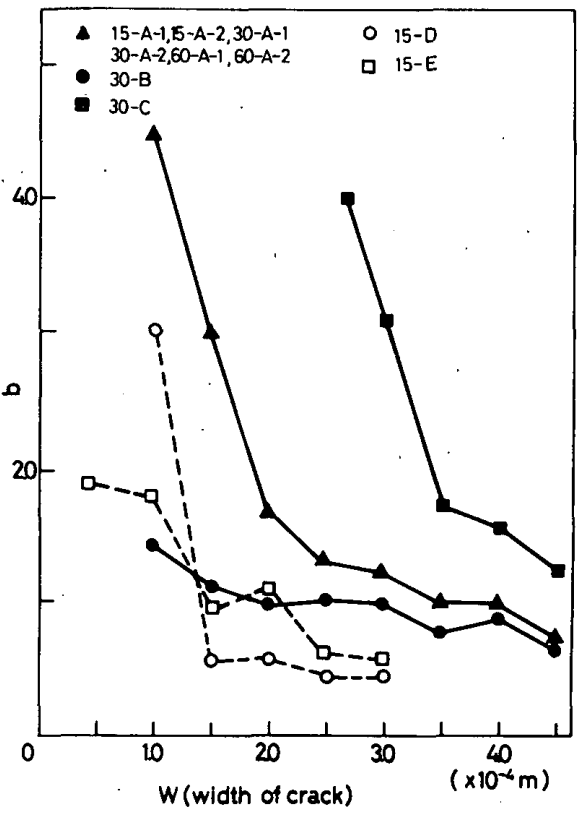

Fig. $15 \quad b-W$ relationship of all the specimens

常のコンクリートであれば，ひびわれの気体漏洩量は

(10) 式および (11) 式で評価できる。A E シリーズ のすべての試験体について,$f \cdot Q-Q$ 関係を直線回帰し たときの切片 $a$, 傾き $b$ とひびわれ幅 $W$ の関係を Fig. 14，Fig.15に示す。いずれの試験体においてもひ びわれ幅の増加とともに，切片，傾きとも減少する傾向 が見られる。理想化したひびわれモデルの気体漏洩に関 する実験結果（Gシリーズ）を考え合わせれば，ひびわ れ幅無限大では, 傾きは零に, 切片は $12 \cdot \mu / \rho_{0}$ に収束す るものと考えられる。Fig. 14 中 $a=12 \cdot \mu / \rho_{0}$ を破線で 示した。また各試験体のひびわれ面の形状を, Fig. 16(a) 〜 (e) に示す。

Fig. 14 でわかるように, 前報での筆者らの予想亡反 して，骨材粒径の大きいコンクリート (30-B) のほう が骨材粒径の小さいコンクリート (30-C) に比へ，同 一条件での漏洩量が多いという結果になった。これは粗 骨材として砕石を用いていたため，粒径の大きい骨材ほ ぞ載荷時に割れる可能性が高く，骨材粒径がひびわれ面 の平滑度に反映されなかったためと考えられる。また, 骨材形状の影響を調べた実験では，球形の骨材を用いた 場合（15-D）のほうが, 立方体の骨材 (15-E) よりも 同一条件下で漏洩量は多いという結果になった。

このようにコンクリートのひびわれ面の摩擦係数はコ ンクリートの骨材粒径, 骨材形状により変化することが 明らかとなった。摩擦係数を決める要因であると考えら れる, あるいは, 前報では係数 $\bar{\alpha}$ を決める要因と考え たひびわれ面の平滑度は, 単純に最大骨材粒径により評 価できるものではなく，その定性的な評価にはまだ多く の実験結果の蓄積を待たねばならない。

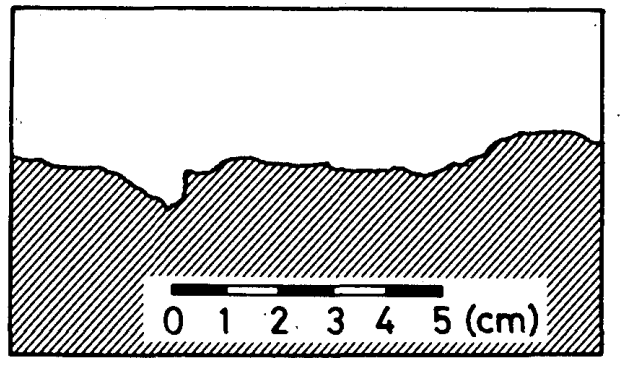

(a) Concrete A

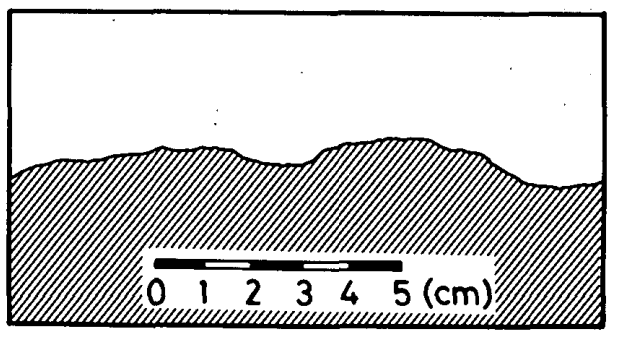

(b) Concrete B

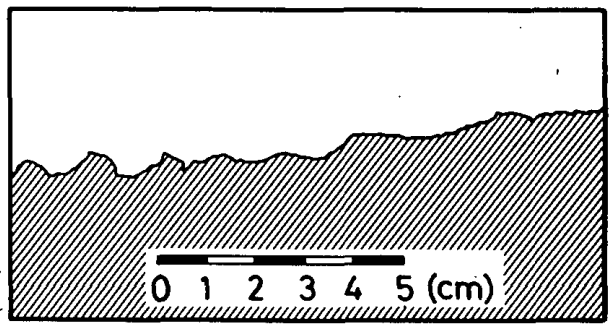

(c) Concrete C

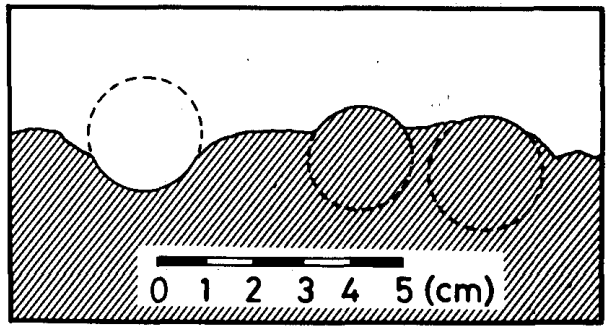

(d) Concrete D

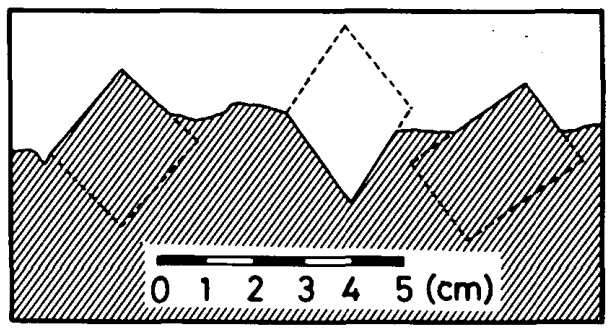

(e ) Concrete E

Fig. 16 Sections of the cracks

\section{§4. コンクリート壁のひびわれからの気体漏洩に関 する実用式の提案}

コンクリート壁のひびわれからの気体漏洩問題が特に 原子力関連施設の設計において重要となっているという 背景を考えると, 対象とする範囲を, 壁の両側の圧力が 大気圧 $\left(1.013 \times 10^{5} \mathrm{~Pa}\right)$ に近く, 圧力差が 0.01 気庄 $\left(10^{2} \mathrm{~Pa}\right.$ のオーダー) 以下に限定し得る場合も少なく ない。このように, 絶対圧力が大気圧に近く, 圧力差の 
極めて小さい範囲を問題にする場合，気体の圧縮性は無 視し得るものと考えられる。実際に, 圧力差と流量が比 例する範囲が存在したことから, 非俚縮, 粘性流体の理 論式（三次元ポアズイユ流）を基に論展開を行ったのが 前報であった。しかしながら，前報における実験式の適 用範囲には，絶対圧力に関する規定がなく，また比例範 曲自体が見かけ上現れるものであり，適用範囲に関する 規定は誤りであった。本章では，コンクリートのひびわ れ内の気体の流れが (10) 式，(11）式に従う流れであ るとして比例範囲が見かけ上現れることを示すととも に，前報の実験式の適用範囲について再検討を行う。 前報における実験式は次式で表される。

$$
Q=\bar{\alpha} \cdot \frac{\Delta p \cdot W^{3}}{\mu \cdot T}
$$

一方（10）式は $Q$ について整理すれば,

$$
Q=\frac{W^{3} \cdot\left(P_{1}+P_{2}\right) \cdot\left(P_{1}-P_{2}\right)}{2 \cdot \rho_{0} \cdot P_{0} \cdot(f \cdot Q) \cdot T}
$$

となる。（13）式，(14）式より，摩擦係数 $f$ と係数 $\bar{\alpha}$ の間に

$$
\bar{\alpha}=\frac{\mu}{\rho_{0} \cdot(f \cdot Q)} \cdot \frac{\left(P_{1}+P_{2}\right)}{2 \cdot P_{0}}
$$

の関係があることがわかる。(15) 式中， $\mu, \rho_{0}, P_{0}$ は定 数である。また $(f \cdot Q)$ は $Q$ の 1 次関数で表され流量の 増加とともに増大する。にもかかわらず，同じひびわれ 幅では流量によらず 量と圧力差の比例範囲が存在したということは，壁両端 の圧力 $P_{1}, P_{2}$ が流量に独立でなかったことを示してい る。

実験では，Fig. 17 中右下に示す面積式流量計を用い, 出口側を自由放流（大気圧に放流）として流量を測定し ていた。ところが流量 $Q$ と，流量計の入口側の圧力,

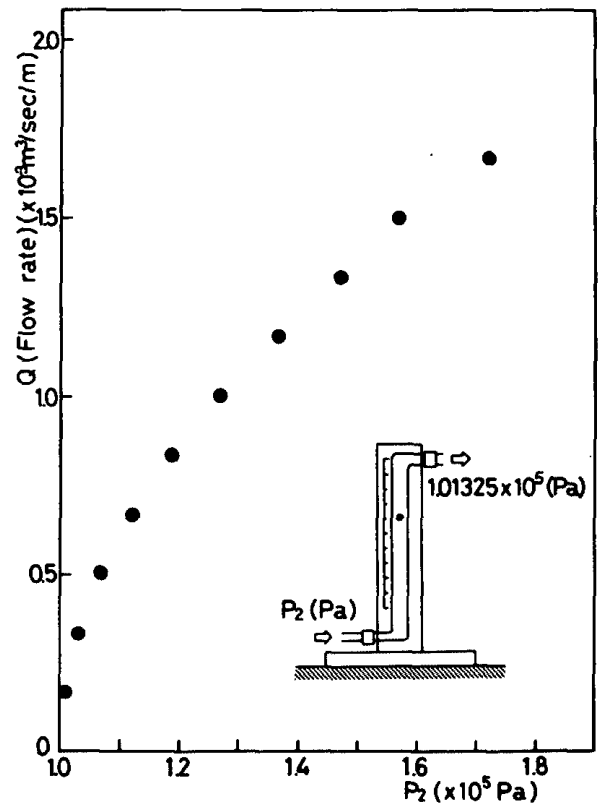

Fig. 17 Property of flow meter

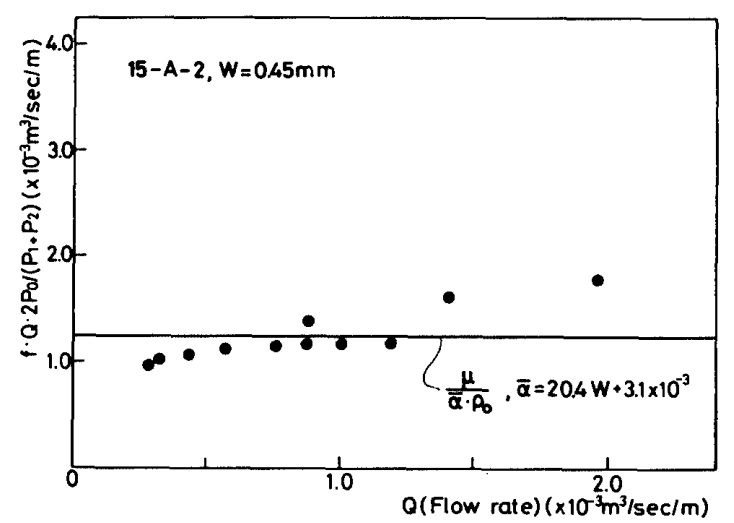

Fig. $18\left[2 \cdot f \cdot Q \cdot P_{0} /\left(P_{1}+P_{2}\right)\right]-[Q]$ relationship of $15-\mathrm{A}-2, W$ $=0.45 \mathrm{~mm}$

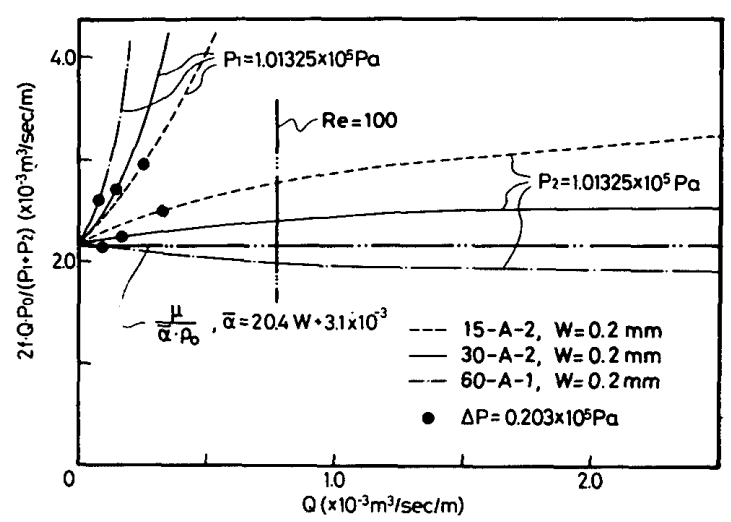

(a) $W=0.20 \mathrm{~mm}$

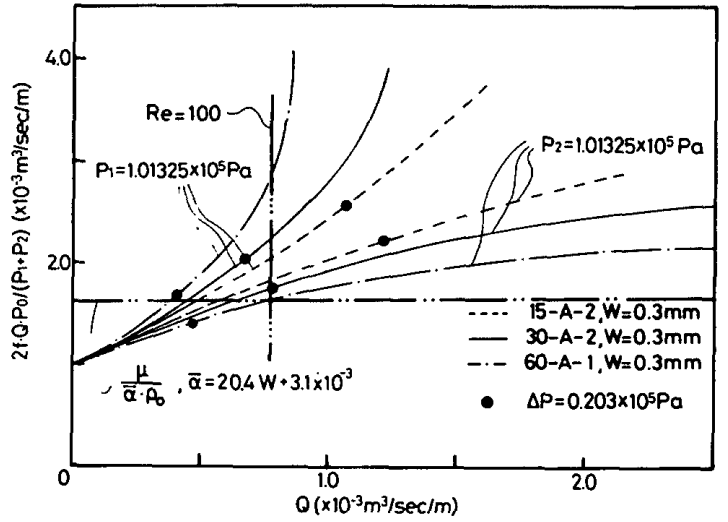

(b) $W=0.30 \mathrm{~mm}$

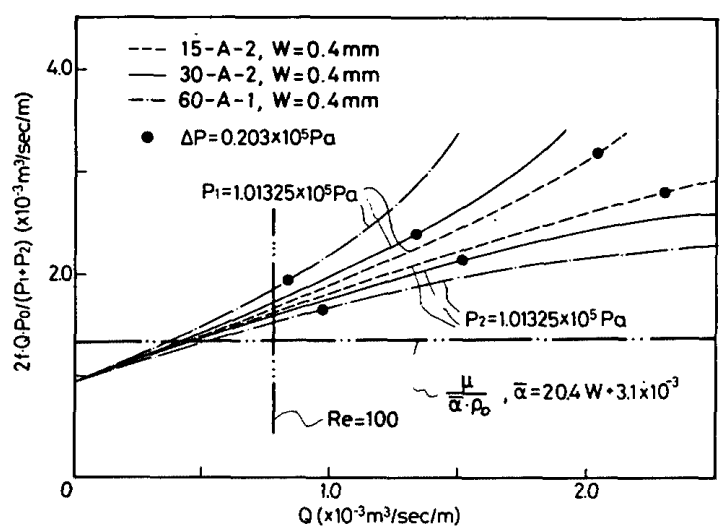

(c) $W=0.40 \mathrm{~mm}$

Fig. $19\left[2 \cdot f \cdot Q \cdot P_{0} /\left(P_{1}+P_{2}\right)\right]-[Q]$ relationship of $15-\mathrm{A}-2$, $30-\mathrm{A}-2$ and $60-\mathrm{A}-1$ 
つまり，壁の流出端の圧力 $P_{1}$ の間には，Fig. 17 に示す ような関係があり, 流量の増加とともに, 壁の流出端の 圧力は增大する。したがって可が一定となっていたの は，(15）式中で流量の増加による $(f \cdot Q)$ の増加分と $\left(P_{1}+P_{2}\right)$ の増加分が釣り合っていたものと考えられる。 Fig. 18 に A シリーズの壁厚 $15 \mathrm{~cm}$ の試験体のひびわれ 幅 $0.45 \mathrm{~mm}$ における $\mu /\left(\bar{\alpha} \cdot \rho_{0}\right)$ に相当する $f \cdot Q \cdot 2 \cdot P_{0} /$ $\left(P_{1}+P_{2}\right)$ と流量 $Q$ の関係を示す。 $Q=1.0 \times 10^{-3}$ $\mathrm{m}^{3} / \mathrm{sec} / \mathrm{m}$ 程度までは $\bar{\alpha}$ はほぼ一定とみなせる。図中の 実線は前報で規定した $\bar{\alpha}$ の式

$$
\left.\bar{\alpha}=20.4 \times W+3.1 \times 10^{-3} \text { ( } W \text { の単位は } \mathrm{m}\right)(16)
$$

より求めた $f \cdot Q \cdot 2 \cdot P_{0} /\left(P_{1}+P_{2}\right)$ を表している。流量と 圧力差の間に比例関係が見られるのは流量計の特性の影 響によるものであった。

次に，(14）式の $f$ より（15）式を用いて求められる $\bar{\alpha}$ と, 前報の実験式における $\bar{\alpha}$ を比較しながら, 前報の 実験式，(13）式の適用範囲について検討する。

Fig.19(a)〜 (c) はA シリーズのコンクリートに関し て, 壁流出端の圧力を $1.013 \times 10^{5} \mathrm{~Pa}$ とした場合および 壁流入端の圧力を. $1.013 \times 10^{5} \mathrm{~Pa}$ とした場合の（14）式 の $f$ より求められる $f \cdot Q \cdot 2 \cdot P_{0} /\left(P_{1}+P_{2}\right)$ 之前報の実験 式の係数 $\bar{\alpha}\left(16\right.$ 式) より求められる $\mu /\left(\bar{\alpha} \cdot \rho_{0}\right)$ の比較を

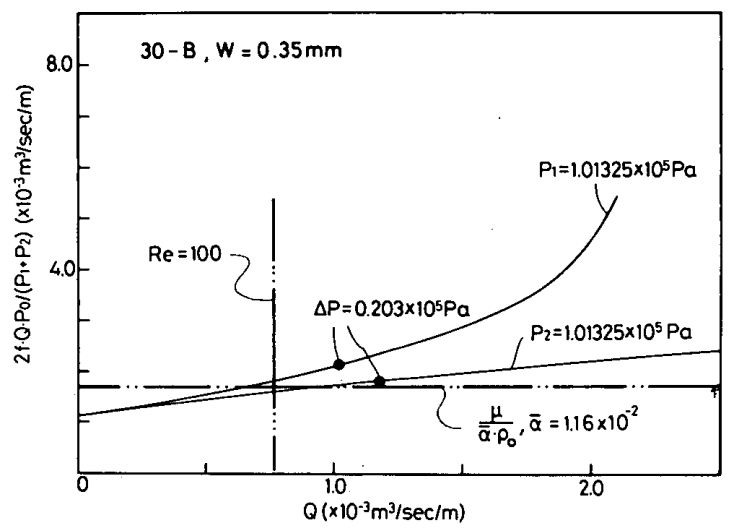

Fig. $20 \cdot\left[2 \cdot f \cdot Q \cdot P_{0}^{\prime} /\left(P_{1}+P_{2}\right)\right]-[Q]$ relationship of $30-\mathrm{B}, W=$ $0.35 \mathrm{~mm}$

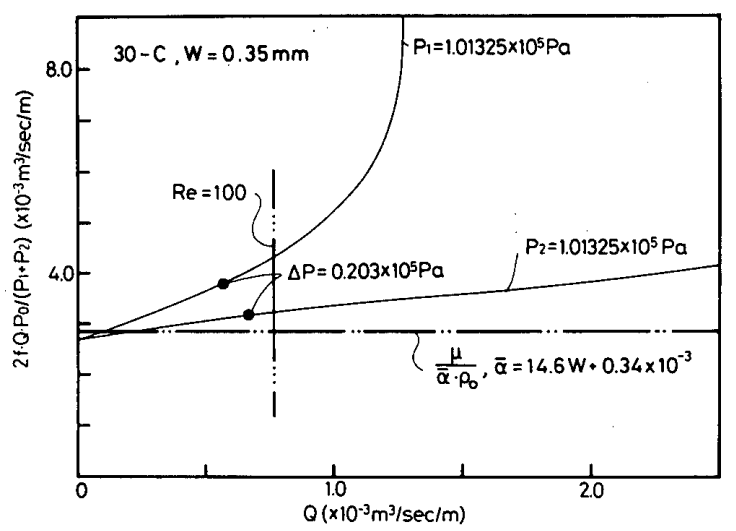

Fig. $21\left[2 \cdot f \cdot Q \cdot P_{0} /\left(P_{1}+P_{2}\right)\right]-[Q]$ relationship of $30-C, W=$ $0.35 \mathrm{~mm}$
行ったものである。図中，破線実線，1点鎖線は，壁厚 $15 \mathrm{~cm}, 30 \mathrm{~cm}, 60 \mathrm{~cm}$ の試験体について, $f$ 上り求めら れる $f \cdot Q \cdot 2 \cdot P_{0} /\left(P_{1}+P_{2}\right)$ の流量による変化を表してい る。また，太線の 2 点鎖線は前報の実験式の係数 $\bar{\alpha}$ を 示している。で壁両端の圧力差が $0.203 \times 10^{5} \mathrm{~Pa}$ (0.2 気圧) となる点を, またー-.で見かけのレイ) ルズ数が 100 となる流量を示した。いずれのひびわれ幅 においても，前報の実験式の $\bar{\alpha}(16)$ 式より求めた $\mu /$ $\left(\bar{\alpha} \cdot \rho_{0}\right)$ は流量が比較的少ない場合（見かけのレイノル ズ数が 100 以下, 圧力差 $\Delta p$ が $0.203 \times 10^{5}$ (0.2 気圧) 以下), (14) 式の摩擦係数 $f$ 上り求めた $f \cdot Q \cdot 2 \cdot P_{0} /$ $\left(P_{1}+P_{2}\right)$ をほぼ評価しているものとみなせる。

Fig. 20〜Fig. 23 は, 同様に B, C, D, E シリーズの コンクリートに関して，(14）式の $f$ より求められる $f \cdot Q \cdot 2 \cdot P_{0} /\left(P_{1}+P_{2}\right)$ と前報と同様の実験結果の整理法 により,

$$
\begin{array}{ll}
\bar{\alpha}=1.16 \times 10^{-2} & (\mathrm{~B} \text { シリーズ }) \cdots(17) \\
\bar{\alpha}=14.6 \times W+0.34 \times 10^{-3} & (\mathrm{C} \text { シリーズ }) \cdots(18) \\
\bar{\alpha}=41.8 \times W+5.44 \times 10^{-3} & (\mathrm{D} \text { シリーズ }) \cdots(19) \\
\bar{\alpha}=35.0 \times W+2.04 \times 10^{-3} & (\mathrm{E} \text { シリーズ }) \cdots(20)
\end{array}
$$

と定式化された $\bar{\alpha}$ より求められた $\mu /\left(\bar{\alpha} \cdot \rho_{0}\right)$ の比較を 行ったものである。いずれの試験体においても，やはり

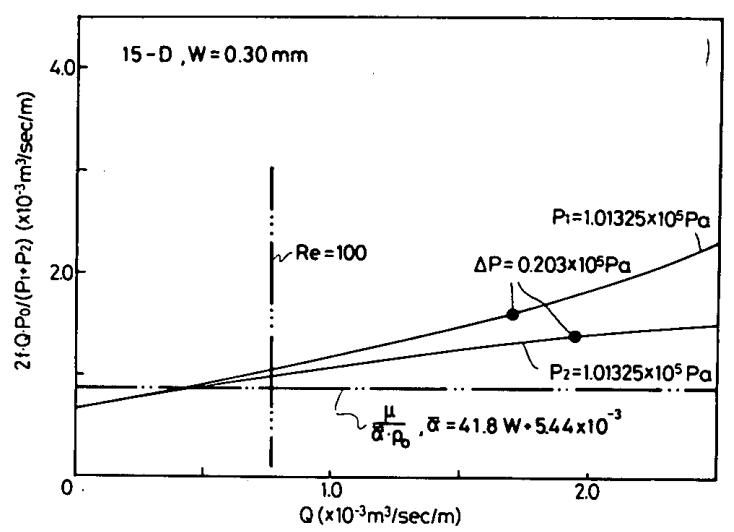

Fig. $22\left[2 \cdot f \cdot Q \cdot P_{0} /\left(P_{1}+P_{2}\right)\right]-[Q]$ relationship of $15-\mathrm{D}, W=$ $0.30 \mathrm{~mm}$

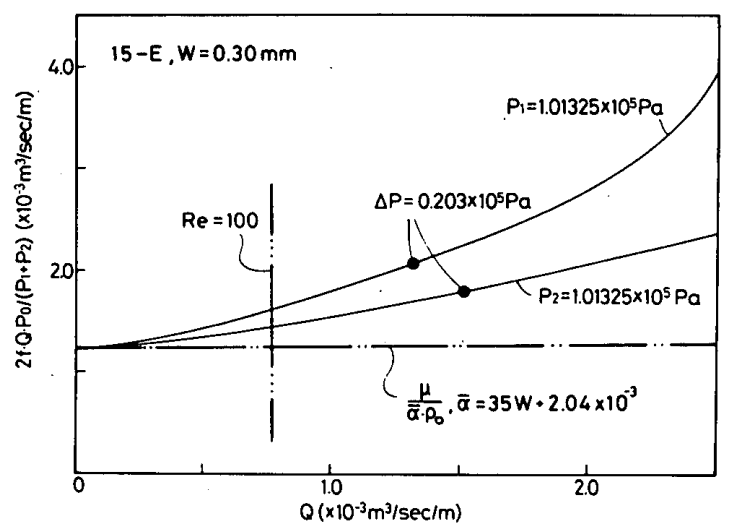

Fig. $23\left[2 \cdot f \cdot Q \cdot P_{0} /\left(P_{1}+P_{2}\right)\right]-[Q]$ relationship of $15-\mathrm{E}, W=$ $0.30 \mathrm{~mm}$ 
見かけのレイノルズ数が 100 以下, 壁両端の告力差 $\Delta p$ が $0.203 \times 10^{5} \mathrm{~Pa}$ (0.2 気生) 以下であれば，両者はよ く対応している。

Fig. 19〜Fig. 23 より, 少なくとも, 絶対圧力 $P_{1}, P_{2}$ が $0.8 \times 10^{5} \mathrm{~Pa}$ から $1.2 \times 10^{5} \mathrm{~Pa}$, 圧力差 $\Delta p$ が $0.2 \times$ $10^{5} \mathrm{~Pa}$ 以下, 見かけのレイノルズ数 $\left(R_{e}=2 \cdot \rho_{0} \cdot Q / \mu\right)$ が $10^{1}$ のオーダーであれば, 前報における実験式 (13) 式によっても，コンクリート壁のひびわれを通しての気 体漏洩量の定量的把握が可能であるといえる。

前述のとおり，コンクリート壁の気体漏洩問題は原子 力関連施設の設定において重要となっており，対象とな る範囲は，ほぼ上述の範囲に内包されている。そこでよ り簡単な形である(13)式をひびわれの生じたコンクリー 卜壁の気体漏洩に関する実用式として提案する。(13) 式は実用式として十分な精度でひびわれの生じたコンク リート壁の気体漏洩量を評価し得る。

\section{§5. 結 論}

ひびわれの生じたコンクリート壁の気体漏洩に関する 実験およびコンクリートのひびわれ内の気体の流れに関 する考察をとおして，以下のような結論を得た。

（1）ひびわれの生じたコンクリート壁からの気体漏 洩量は, 圧縮性流体の一次元定常等温流れを表す式を利 用した実験式（10）式によって評価することができる。

（2）（10）式におけるひびわれ面の摩擦係数 $f$ は流 量 $Q$ およびひびわれ幅 $W$ の関数となっており，(11) 式で表される。
（3）少なくとも以下に示す範囲内において, 二次元 ポアズイユ流を表す式を利用した実験式（13）式によっ ても, 十分な精度でひびわれの生じたコンクリート壁か らの気体漏洩量を把握し得る。

$0.8 \times 10^{5} \mathrm{~Pa} \leqq$ 壁両端の絶対圧力 $P_{1}, P_{2}$

$$
\leqq 1.2 \times 10^{5} \mathrm{~Pa}
$$

壁両端の告力差 $\Delta p \leqq 0.2 \times 10^{5} \mathrm{~Pa}$

見かけのレイノルズ数 $R_{e}\left(=2 \cdot \rho_{0} \cdot Q / \mu\right) \leqq 10^{2}$

(4) (10) 式の摩擦係数, あるいは（13）式の係数 人はコンクリートの骨材粒径, 骨材形状等によって変化 する。

（5）（3）に示した条件が満たされる場合の実用式 としては，より簡単な形である（13）式を推奨する。

謝 辞

実験および資料整理には東京工大建築学科, 鈴木・滝 口研究室の学生に全面的に協力していただいた。本研究 には筆者の一人が文部省科学研究費補助金をいただいて おります。心より感謝いたします。

\section{参考文献}

1）鈴木敏郎, 滝口克己, 井出 豊, 内山政彦:ひびわれの 生じたコンクリート壁からの気体漏洩に関する基礎的実 験: 日本建築学会構造系論文報告集, 第 373 号, 昭和 62 年 3 月

2）小茂鳥和生 : 非接触シール論, コロナ社, 1973 年版

3) 生井武文, 松尾一泰: 压縮性流体の力学, 理工学社, 1986 年版 


\section{SYNOPSIS}

UDC : 69.002. $1: 66.078 .2: 539.213$

EXPERIMENTAL STUDY ON THE LEAKAGE OF GAS THROUGH CRACKED CONCRETE WALLS

-Investigation of the experimental formula by considering the compressibility of gas-

by TOSHIRO SUZUKI, Professor of Tokyo Institute of Technology, Dr. Eng., KATSUKI TAKIGUCHI, Associate Professor of Tokyo Institute of Technology, Dr. Eng., HISATO HOTTA, Ressearch Associate of Tokyo Institute of Technology, and YUTAKA IDE, Graduate Student of Tokyo Institute of Technology, Members of A. I. J.

In the previous paper(Trans. of A.I.J. No.373), the degree of gas leakage through a single crack in a concrete wall was discussed and the following equation was proposed to estimate the leakage rate :

$$
Q=\bar{\alpha} \cdot \Delta p \cdot W^{3} /(\mu \cdot T)
$$

where $W=$ crack width, $T=$ wall thickness,

$\mu=$ viscosity of gas,

$\Delta p=$ pressure differential across the wall, coefficient $\bar{\alpha}$ is a function of $W$ (crack width).

This paper deals with additional leakage tests and new equations.

In order to study the effect of irregularities of crack surfaces, leakage tests were executed using four kinds of concrete. Leakage test of an idealized crack made of two parallel glass plates was also carried out.

In this paper, the leakage test results were arranged by taking into account the compressibility effects on the gas flow. Conclusions are as follows.

1) $Q$ (leakage rate) can be estimated by the following equation:

$$
\begin{aligned}
& f=W^{3} \cdot\left(P_{1}^{2}-P_{2}^{2}\right) /\left(2 \cdot P_{0} \cdot Q^{2} \cdot \rho_{0} \cdot T\right) \\
& f=a(W) / Q+b(W)
\end{aligned}
$$

where $P_{1}=$ pressure at the inflow pressure box,

$P_{2}=$ pressure at the outflow pressure box,

$P_{0}=1.01325 \times 10^{5}(\mathrm{~Pa})$,

$\rho_{0}=$ density of gas,

$f=$ coefficient of friction,

$a(W)$ and $b(W)$ are experimental functions.

2) The coefficient of friction $\mathrm{f}$ is influenced by the particle diameter of aggregate and the shape of aggregate.

3) To say the least, in the range of $0.8 \times 10^{5}(\mathrm{~Pa}) \leqq P_{1}, P_{2} \leqq 1.2 \times 10^{5}(\mathrm{~Pa}), \Delta p \leqq 0.2 \times 10^{5}(\mathrm{~Pa}), R_{e}$ (apparent Reynolds' number) $\leqq 10^{2}$, the equation presented in the previous paper can be applicable and can be recommendable for practical use. 